\title{
ANALYSIS OF THE RISK OF LIQUIDATION DEPENDING ON THE AGE OF THE COMPANY: A STUDY OF ENTITIES ESTABLISHED IN SZCZECIN IN PERIOD 1990-2010
}

\author{
Iwona Markowicz \\ Univeristy of Szczecin, Szczecin, Poland \\ e-mail: iwona.markowicz@usz.edu.pl \\ ORCID: 0000-0003-1119-0789 \\ (C) 2019 Iwona Markowicz \\ This is an open access article distributed under the Creative Commons Attribution-NonCommercial- \\ -NoDerivs license (http://creativecommons.org/licenses/by-nc-nd/3.0/)
}

DOI: 10.15611/eada.2019.2.04

JEL Classification: C10, C14, C41

\begin{abstract}
The aim of the research was an assessment of the relative risk of liquidation of a company depending on its age. The research covered economic entities established in Szczecin in the period 1990-2010. The analysis was carried out with the use of a logit model. The risk of company liquidation was examined depending on the entity's age expressed both in months (continuous variable) and in grouped intervals (year, half-year). In this way, attention was drawn to the benefits of continuous variable coding (rank and 0-1 coding). The research covered companies established during 1990-2010 in total (over 120 thousand) and in time periods resulting from the cyclical character of liquidation of companies (in accordance with the earlier research findings). The research showed that the risk of company liquidation decreases as the company grows older (the use of a continuous variable and a rank variable). On the other hand, the risk of subsequent age groups (using the $0-1$ variable) prevents the risk from being monotonous.
\end{abstract}

Keywords: survival analysis, firms' duration, risk of liquidation.

\section{Introduction}

According to the literature, the age of a company is important for its prospects of survival in the subsequent periods. According to the liability of newness - one of the concepts of company survival derived from the theory of company organization [Poznańska 2008], the most important factor of survival is the longevity of business activity on the market (start-ups tend to leave the market quickly). The importance of company longevity is also emphasized by the theoretical model of learning which assumes that the entrepreneur needs time to determine whether their company will be able to operate in the market [Ericson, Pakes 1998; Bhattacharjee 2005]. The results of many studies [Caves 1998; Carroll, Hannan 2000; Praag 2003] suggest that 
the age, size and duration of enterprises are interlinked. In the Polish literature one can find the results of research concerning the survival time of entities established in different cities or voivodships [Dehnel 2010; Markowicz 2012; Nehrebecka, Dzik 2013; Jackowska 2015; Ptak-Chmielewska 2016; Gurgul, Zając 2016; Mikulec 2018; Markowicz, Mikulec 2018].

The aim of the research was an assessment of the relative risk of liquidation of a company depending on its age. The research covered economic entities established in Szczecin in 1990-2010. The analysis was carried out with the use of a logit model. The risk of company liquidation was examined depending on the entity's age expressed both in months (continuous variable) and in grouped intervals. In this way, attention was drawn to the benefits of continuous variable coding. The research covered companies established in the period 1990-2010 and in time periods resulting from the cyclical character of liquidation of companies [Markowicz 2018]. The results of earlier research pointed to the cyclicality of the relative risk of non-survival of the first year of activity by entities from subsequent cohorts (entities established in subsequent years from 1990 to 2010).

\section{Statistical data and research methodology}

The survey used individual data for 120,115 companies established in Szczecin between 1990-2010 and observed for up to four years. Data on the lifespan of companies liquidated during the observation period were considered to be complete data, while censored data refer to companies operating until the end of the observation period.

The risk of liquidation of the company was assessed using a logit model. The model explained the impact of specific variables on the occurrence or absence of the event under investigation. Transformation of the logistic model into a logit model caused a change of the scale for probability from 0 to 1 to the scale from minus to plus infinity [Wiśniewski 1989; Jajuga 1990; Gatnar, Walesiak (eds.) 2004].

The analysis of the risk is conducted by means of the logit model written as [Kleinbaum, Klein 2005; Gruszczyński (ed.) 2012]:

$$
\operatorname{logit}(p)=\ln \left(\frac{p}{1-p}\right)=\alpha_{0}+\sum_{i=1}^{k} \alpha_{i} x_{i},
$$

where: $p=P\left(Y=1 \mid x_{1}, x_{2}, \ldots, x_{k}\right)-$ conditional probability of an event occurring with $k$ independent variables $x_{1}, x_{2}, \ldots, x_{k} ; \alpha_{1}, \alpha_{2}, \ldots, \alpha_{k}$ - model coefficients.

The value $p$ refers to the probability of failure (the company's liquidation), and the expression $\frac{p}{1-p}$ means the risk for a specific event to occur. The bigger the value of the regression coefficient $\alpha_{i}$, the stronger the impact of the explanatory variable on the probability of the event occurring. 
The resulting parameter estimates and their interpretation depend on the way the explanatory variables are written. We may use quantitative variables (continuous and discrete variables), suitably dimensioned qualitative characteristics and grouped values or variants of one characteristic [Bednarski, Mocarska, 2006; Bieszk-Stolorz, Markowicz 2017].

The study used three ways to define an independent variable, i.e. the age of the company: a continuous variable $x_{i}$ expressed in months, a $k$-variant (rank) variable $x$ expressed in years $(k=1, \ldots, 4)$ or half-years $(k=1, \ldots, 8)$ and dummy dichotomous variables $x_{i}$ representing age groups.

For the $k$-variant variable $x$, the rank coding was used, as follows:

- for age groups in years (groups $1, \ldots, 4)-x=1$ for company age from the interval $<0-1), x=2$ for company age from the interval $<1-2$ ), $x=3$ for company age from the interval $<2-3$ ), $x=4$ for company age from the interval $<3-4$ ),

- for age groups in half-years (groups $1, \ldots, 8)-x=1$ for company age from the interval $<0-6$ ) months, $x=2$ for company age from the interval $<6-12$ ) months, $\ldots, x=8$ for company age from the interval $<42-48$ ) months.

In the third approach to the coding of explanatory variables, the dummy dichotomous variables $x_{i}$ were created taking values of 0 or 1 according to the definition presented in Table 1.

Table 1. Defining of dichotomous explanatory variables

\begin{tabular}{|c|c|c|}
\hline Variables & Value 1 & Value 0 \\
\hline \multicolumn{3}{|c|}{ Age groups in years } \\
\hline$x_{1}$ & \multicolumn{2}{|c|}{ the reference point, age from the interval $<0-1$ ) } \\
\hline$x_{2}$ & for age from the interval $<1-2$ ) & \multirow{3}{*}{ In other incidentals } \\
\hline$x_{3}$ & for age from the interval $<2-3$ ) & \\
\hline$x_{4}$ & for age from the interval $<3-4$ ) & \\
\hline \multicolumn{3}{|c|}{ Age groups in months (half-years) } \\
\hline$x_{1}$ & \multicolumn{2}{|c|}{ the reference point, age from the interval $<0-6$ ) } \\
\hline$x_{2}$ & for age from the interval $<6-12$ ) & \multirow{4}{*}{ In other incidentals } \\
\hline$x_{3}$ & for age from the interval $<12-18$ ) & \\
\hline$\vdots$ & $\vdots$ & \\
\hline$x_{8}$ & for age from the interval $<42-48$ ) & \\
\hline
\end{tabular}

Source: own elaboration.

The variable with $k$ variants was transformed into $k-1$ so-called design variables or dummy variables. One of the variants was a variable which had not been introduced into the model (due to its collinearity), but which was the reference point for other dummy variables. 
The survey was conducted in three stages. The first one covered companies established in the entire period under examination, i.e. the years between 1990-2010. The subsequent stages were identified on the basis of earlier research [Markowicz 2018], which showed that the risk of liquidation of companies runs in cycles. Taking into consideration the risk of liquidation in the first (most difficult) year of operation, two cycles covering the years 1990-2001 and 2002-2010 and four phases were determined: the rise in the years 1990-1997 (increasing risk of liquidation in subsequent cohorts of companies), the decrease in 1998-2001 (declining risk), the rise in 2002-2006 followed by the downward phase in 2007-2010. The results of the study are shown in a sequence of three stages. In each stage the results of the application of the explanatory variable (company age) in the form of a continuous variable, the rank variable and binary $(0-1)$ variables are presented.

\section{Research results}

\subsection{The period of company establishment: 1990-2010}

When the continuous variable (the company's age in months) was used in the logit model, we obtained: $\left(\chi^{2}=110513.1 ; p=0.0000\right)$ :

$$
\begin{aligned}
\operatorname{logit}(p)= & 19.4237-0.5661 \cdot x_{i} \\
& (0.2004)(0.0054)
\end{aligned}
$$

The risk ratio $\left(\exp \left(\alpha_{i}\right)\right)$ was $0.5678(p=0.0000)$, which should be interpreted as: with the increase in the age of the company by one month, the risk of liquidation decreases by $43.22 \%$. This result was too general, averaged and did not indicate the differences in the risk of companies of different ages. Then, models for the rank variable (groups 1 to 4 ) and the $0-1$ variables were estimated (Table 2, Figure 1). As a result of using a rank variable defining four groups of companies (one, two, three and four-year-old), the risk of each successive group was found to be lower by $24.29 \%$. This is how much the risk of liquidation dropped with the increase in the age of the company by one year. At this point it should be noted that that was still an average result. In order to indicate the differences in the risk of individual groups, the variables $0-1$ should be used. Therefore, the rank variable with $k$ variants was transformed into $k$ dichotomous variables. The first one was considered the reference group. It turned out that in relation to one-year-old companies (liquidation in the first year of operation) the risk of liquidation of two-year-old companies (liquidation at the age of 1 to 2 years) was lower by $6.27 \%$, of three-year-old companies by $15.40 \%$, and of four-year-old companies by as much as $68.87 \%$. Accordingly, the use of the artificial dummy variable $(0-1)$ as an explanatory variable makes it possible to differentiate company groups according to their age in terms of the risk of liquidation. 
Table 2. Results of the logit model estimation for the period 1990-2010 using the rank variable and $0-1$ variables (age in years)

\begin{tabular}{|c|c|c|c|c|}
\hline Variables & Parameters estimator & Standard error & $p$-value & Risk ratio \\
\hline \multicolumn{5}{|c|}{ Rank variable $x$} \\
\hline$x$ & -0.2782 & 0.0053 & 0.0000 & 0.7571 \\
\hline \multicolumn{5}{|c|}{0 -1 variables $x_{i}$} \\
\hline$x_{1}$ & -0.0648 & 0.0141 & 0.0000 & 1 \\
\hline$x_{2}$ & -0.1673 & 0.0148 & 0.0000 & 0.9373 \\
\hline$x_{3}$ & -1.1669 & 0.0208 & 0.0000 & 0.8460 \\
\hline$x_{4}$ & &
\end{tabular}

Source: own research.

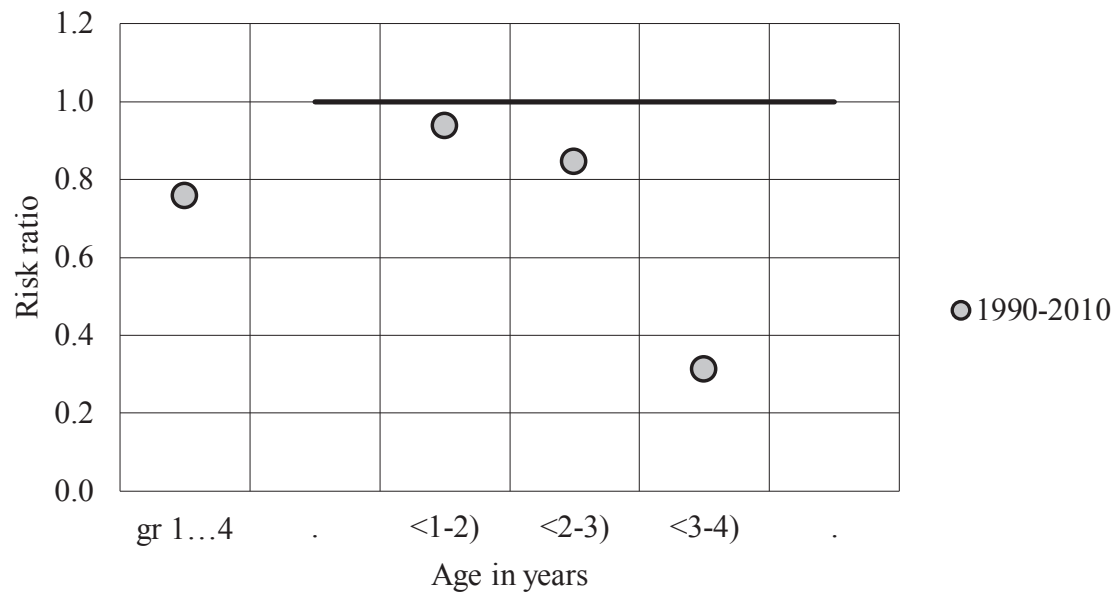

Fig. 1. Risk ratio of company liquidation for variables: rank and 0-1 (age in years)

Source: own research.

Models were also estimated for the rank variable (groups 1-8) and the 0-1 variables, where age was expressed in half-years (Table 3, Figure 2). As a result of using a rank variable which defined eight groups of companies (in age sequence: $<0-6),<6-12), \ldots,<42-48$ ) months), it was found that the risk of each successive group was on average $2.22 \%$ lower. In the dichotomous variables approach, companies that were liquidated before reaching six months of operation were used as a reference group. For the subsequent groups (companies aged 6-12 and 12-18 months) the risk of liquidation was $13.80 \%$ and $5.29 \%$ higher than the risk of the reference group, respectively. The risk born by the next two groups of companies (aged 18-24 and 24-30 months) slightly differed from the risk of the youngest companies ( $4.59 \%$ lower and $1.23 \%$ higher respectively). The parameters of the two 
variables were insignificant (Table 3). However, this is not a reason to remove these variables from the model, as they have an informative value [Markowicz 2012]. The results indicate that the differences between the risk of liquidation of companies aged 6 months or younger and companies aged 18-24 and 24-30 months were not significant. Therefore, the risk in these groups was similar. The risk ratio for the three oldest groups of companies was below one, which indicates that the risk of these companies was lower than that of the youngest companies by $19.59 \%, 49.41 \%$ and $82.66 \%$, respectively. Therefore, the risk of liquidation in ageing companies was not monotonous, and decreased only in groups of companies over 30 months of age.

Table 3. Results of the logit model estimation for the period 1990-2010 using the rank variable and $0-1$ variables (age in half-years)

\begin{tabular}{|c|c|c|c|c|}
\hline Variables & Parameters estimator & Standard error & $p$-value & Risk ratio \\
\hline \multicolumn{5}{|c|}{ Rank variable $x$} \\
\hline$x$ & -0.0224 & 0.0004 & 0.0000 & 0.9778 \\
\hline \multicolumn{5}{|c|}{0 -1 variables $x_{i}$} \\
\hline$x_{1}$ & 0.1293 & 0.0186 & 0.0000 & 1 \\
\hline$x_{2}$ & 0.0516 & 0.0192 & 0.0073 & 1.1380 \\
\hline$x_{3}$ & -0.0470 & 0.2000 & 0.0186 & 0.9541 \\
\hline$x_{4}$ & 0.0122 & 0.0199 & 0.5414 & 1.0123 \\
\hline$x_{5}$ & -0.2181 & 0.0215 & 0.0000 & 0.8041 \\
\hline$x_{6}$ & -0.6814 & 0.0252 & 0.0000 & 0.5059 \\
\hline$x_{7}$ & -1.7522 & 0.0387 & 0.0000 & 0.1734 \\
\hline$x_{8}$ & & & & \\
\hline
\end{tabular}

Source: own research.

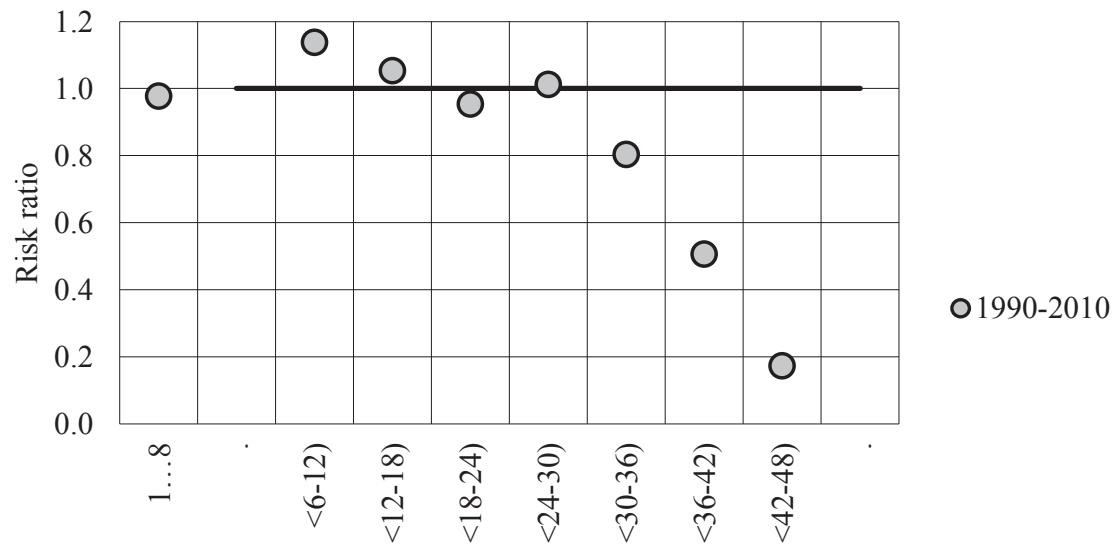

Age in months (half-years)

Fig. 2. Risk ratio of company liquidation for variables: rank and 0-1 (age in half-years)

Source: own research. 


\subsection{The period of company establishment: 1990-2001 and 2002-2010 (two cycles)}

Due to the cyclical character of the risk of company liquidation, the period of observation was divided into two (according to the determined cycles): 1990-2001 and 2002-2010. The procedure of using continuous rank and 0-1 variables was repeated as in Chapter 3.1. When the continuous variable was used in the logit model we obtained:

- for the period 1990-2001 $\left(\chi^{2}=66024.0 ; p=0.0000\right)$ :

$$
\begin{aligned}
\operatorname{logit}(p)= & 19.5762-0.5751 \cdot x_{i}, \\
& (0.2752)(0.0074)
\end{aligned}
$$

- for the period 2002-2010 $\left(\chi^{2}=43544.0 ; p=0.0000\right)$ :

$$
\begin{aligned}
\operatorname{logit}(p)= & 19.0658-0.5493 \cdot x_{i} \\
& (0.2921)(0.0078)
\end{aligned}
$$

The risk ratios were $0.5627(p=0.0000)$ and $0.5773(p=0.0000)$, respectively, which means that with the increase in company age by one month, the risk of liquidation decreased on average by $43.73 \%$ in the first period and by $42.27 \%$ in the second period. Thereafter, models for the ranked variable (groups 1-4) and the 0-1

\begin{tabular}{|c|c|c|c|c|c|}
\hline Periods & Variables & $\begin{array}{l}\text { Parameters } \\
\text { estimator }\end{array}$ & Standard error & $p$-value & Risk ratio \\
\hline \multicolumn{6}{|c|}{ Rank variable $x$} \\
\hline 1990-2001 & \multirow{2}{*}{$x$} & -0.3616 & 0.0073 & 0.0000 & 0.6965 \\
\hline $2002-2010$ & & -0.1702 & 0.0079 & 0.0000 & 0.8435 \\
\hline \multicolumn{6}{|c|}{0 -1 variables $x_{i}$} \\
\hline \multirow{4}{*}{ 1990-2001 } & $x_{1}$ & & & & 1 \\
\hline & $x_{2}$ & -0.1734 & 0.0185 & 0.0000 & 0.8339 \\
\hline & $x_{3}$ & -0.4317 & 0.0203 & 0.0000 & 0.6494 \\
\hline & $x_{4}$ & -1.3583 & 0.0283 & 0.0000 & 0.2571 \\
\hline \multirow{4}{*}{ 2002-2010 } & $x_{1}$ & & & & 1 \\
\hline & $x_{2}$ & 0.0916 & 0.0219 & 0.0000 & 1.0959 \\
\hline & $x_{3}$ & 0.1706 & 0.0222 & 0.0000 & 1.1861 \\
\hline & $x_{4}$ & -0.8965 & 0.0310 & 0.0000 & 0.4080 \\
\hline
\end{tabular}
variables (Table 4, Figure 3) were estimated. The risk of liquidation in companies

Table 4. Results of the logit model estimation for the periods 1990-2001 and 2002-2010 using the rank variable and $0-1$ variables (age in years)

Source: own research. 


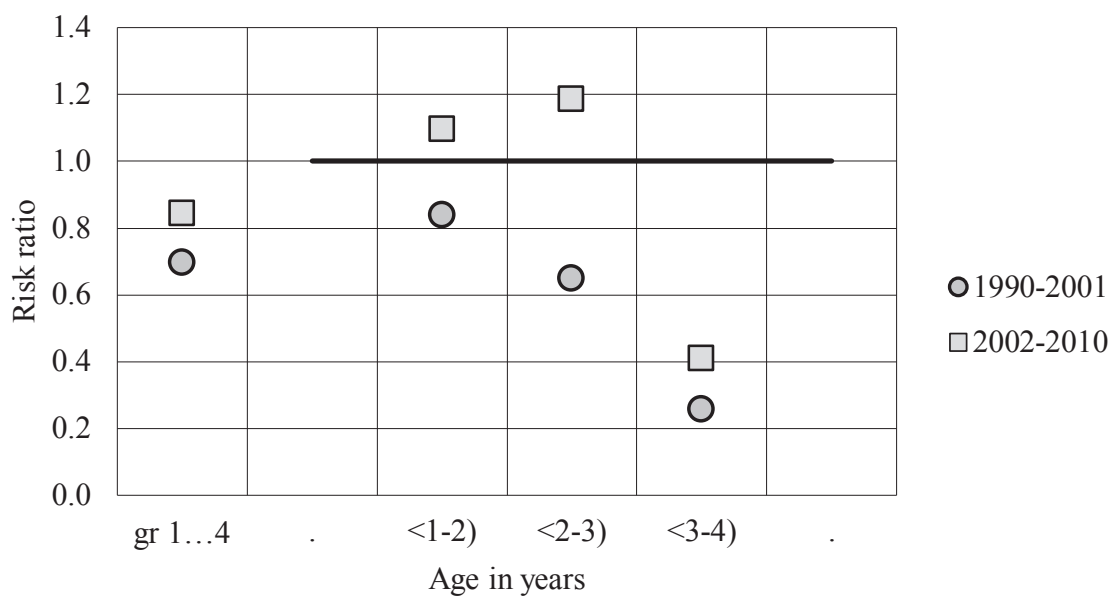

Fig. 3. Risk ratio of company liquidation for variables: rank and 0-1 (age in years) for the periods 1990-2001 and 2002-2010

Source: own research.

ageing by one year decreased by $30.35 \%$ in the first period and by $15.65 \%$ in the second period. When analysing the results of modelling with the use of dichotomous variables, it should be noted that in the period 1990-2001 the risk of liquidation in subsequent age groups was decreasing in comparison to the companies liquidated in the first year of their activity. On the other hand, in the period between 2002-2010, the risk initially increased to drop only in the group of the oldest companies. Therefore, the conditions of running a business activity were more favourable for entrepreneurs in the first period of study, when the risk of liquidation was systematically decreasing together with the company age.

Models for the rank variable (groups 1-8) and the 0-1 variables where age was expressed in half-years were also re-estimated (Table 5, Figure 4). As a result of using a rank variable that defined eight groups of companies (age $<0-6),<6-12), \ldots$, $<42-48$ months), it was found that in each successive group the risk was on average $2.83 \%$ lower in the first period and $1.41 \%$ lower in the second period. In the model with $0-1$ variables, companies that were liquidated before reaching six months of age were again accepted as the reference group. In the first cycle, the risk of liquidation was higher than for the youngest companies only in the case of entities aged from 6 to 12 months. For all other groups the value of relative risk was below one (in the case of the variable $x_{3}$ the parameter was insignificant, i.e. the risk of liquidation for companies aged from 12 to 18 months did not differ significantly from the risk in the reference group). In the second analysed cycle (2002-2010), the risk of groups 2-5 was higher than that of the youngest companies (even by as much as $54.95 \%$ in the case of entities aged 24-30 months). The risk of liquidation of the next group 
Table 5. Results of the logit model estimation for the periods 1990-2001 and 2002-2010 using the rank variable and $0-1$ variables (age in half-years)

\begin{tabular}{|c|c|c|c|c|c|}
\hline Periods & Variables & Parameters estimator & Standard error & $p$-value & Risk ratio \\
\hline \multicolumn{6}{|c|}{ Rank variable $x$} \\
\hline $1990-2001$ & $x$ & -0.0287 & 0.0006 & 0.0000 & 0.9717 \\
\hline $2002-2010$ & $x$ & -0.0142 & 0.0006 & 0.0000 & 0.9859 \\
\hline \multicolumn{6}{|c|}{$0-1$ variables $x_{i}$} \\
\hline \multirow{8}{*}{ 1990-2001 } & $x_{1}$ & & & & 1 \\
\hline & $x_{2}$ & 0.1021 & 0.0239 & 0.0000 & 1.1075 \\
\hline & $x_{3}$ & -0.0351 & 0.0250 & 0.1597 & 0.9655 \\
\hline & $x_{4}$ & -0.2102 & 0.0265 & 0.0000 & 0.8104 \\
\hline & $x_{5}$ & -0.3498 & 0.0279 & 0.0000 & 0.7049 \\
\hline & $x_{6}$ & -0.3916 & 0.0286 & 0.0000 & 0.6760 \\
\hline & $x_{7}$ & -0.9366 & 0.0347 & 0.0000 & 0.3920 \\
\hline & $x_{8}$ & -1.8423 & 0.0503 & 0.0000 & 0.1585 \\
\hline \multirow{8}{*}{$2002-2010$} & $x_{1}$ & & & & 1 \\
\hline & $x_{2}$ & 0.1716 & 0.0298 & 0.0000 & 1.1872 \\
\hline & $x_{3}$ & 0.1789 & 0.0302 & 0.0000 & 1.1959 \\
\hline & $x_{4}$ & 0.1776 & 0.0306 & 0.0000 & 1.1943 \\
\hline & $x_{5}$ & 0.4379 & 0.0295 & 0.0000 & 1.5495 \\
\hline & $x_{6}$ & 0.0338 & 0.0329 & 0.3042 & 1.0342 \\
\hline & $x_{7}$ & -0.3370 & 0.0372 & 0.0000 & 0.7139 \\
\hline & $x_{8}$ & -1.6032 & 0.0605 & 0.0000 & 0.2013 \\
\hline
\end{tabular}

Source: own research.

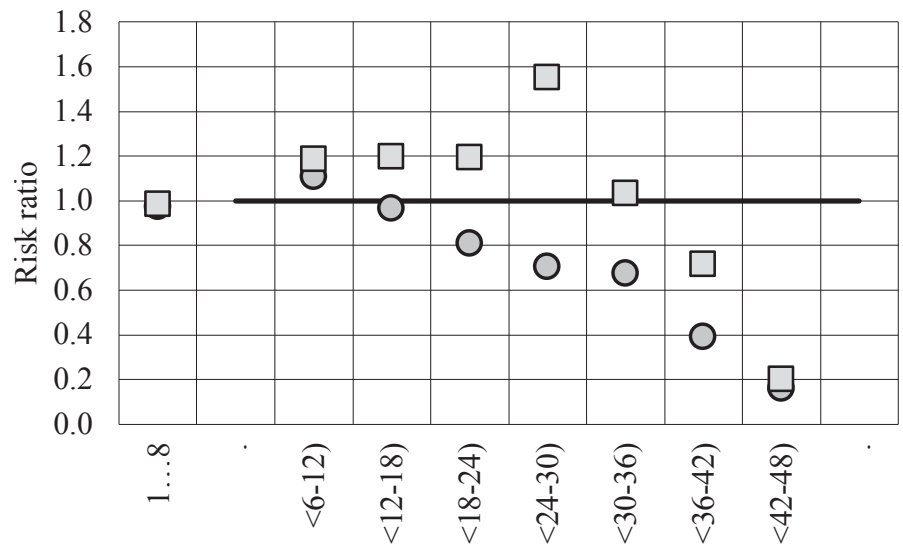

1990-2001

$\square 2002-2010$

Age in years

Fig. 4. Risk ratio of company liquidation for variables: rank and 0-1 (age in half-years) for the periods 1990-2001 and 2002-2010

Source: own research. 
$\left(x_{6}\right)$ did not differ significantly from the youngest group. On the other hand, once the company reached the age of three years, the risk decreased.

\subsection{The period of company establishment: 1990-1997, 1998-2001, 2002-2006 and 2007-2010 (four phases)}

Since the results of earlier surveys indicated that there were four phases of change in the risk of liquidation in the first year of business operation, the analysed period was also divided into four parts. The procedure of using continuous rank and 0-1 variables was repeated again. When the continuous variable was used in the logit model, we obtained:

- for the period 1990-1997 ( $\left.\chi^{2}=2112.9 ; p=0.0000\right)$ :

$$
\begin{aligned}
\operatorname{logit}(p)= & -1.7075-0.4016 \cdot x_{i}, \\
& (0.0203)(0.0091)
\end{aligned}
$$

- for the period 1998-2001 $\left(\chi^{2}=574.5 ; p=0.0000\right)$ :

$$
\begin{aligned}
\operatorname{logit}(p)= & -1.9058-0.2867 \cdot x_{i} \\
& (0.0287)(0.0122)
\end{aligned}
$$

- for the period 2002-2006 $\left(\chi^{2}=368.3 ; p=0.0000\right)$ :

$$
\begin{aligned}
\operatorname{logit}(p)= & -1.7247-0.2145 \cdot x_{i} \\
& (0.0272)(0.0113)
\end{aligned}
$$

- for the period 2007-2010 $\left(\chi^{2}=136.5 ; p=0.0000\right)$ :

$$
\begin{aligned}
& \operatorname{logit}(p)=-1.8727-0.1277 \cdot x_{i} \\
&(0.0273)(0.0110)
\end{aligned} .
$$

The risk ratios $\left(\exp \left(\alpha_{i}\right)\right)$ in the individual phases were as follows: 0.5707 $(p=0.0000), 0.5470(p=0.0000), 0.5764(p=0.0000)$ and $0.5784(p=0.0000)$, which means that along with an increase in the age of the company by one month, the risk of liquidation decreased on average by $42.93 \%$ in the first period, by $45.30 \%$ in the second period, by $42.36 \%$ in the third period and by $42.16 \%$ in the fourth one. The models for the ranked variable (groups 1 to 4 ) and the $0-1$ variables were then estimated (Table 6, Figure 5). The risk of liquidation was decreasing with a company ageing by one year in the first phase by $33.07 \%$, in the second phase by $24.92 \%$, in the third by $19.30 \%$, and in the fourth by $11.99 \%$. When analysing the results of modelling with the use of dichotomous variables, it should be noted that in the first two phases (1990-1997 and 1998-2001) the risk of liquidation decreased in subsequent age groups in comparison to the companies liquidated in the first year 
Table 6. Results of the logit model estimation for the periods 1990-1997, 1998-2001, 2002-2006 and 2007-2010 using the rank variable and 0-1 variables (age in years)

\begin{tabular}{|c|c|c|c|c|c|}
\hline Periods & Variables & Parameters estimator & Standard error & $p$-value & Risk ratio \\
\hline \multicolumn{6}{|c|}{ Rank variable $x$} \\
\hline 1990-1997 & $x$ & -0.4016 & 0.0091 & 0.0000 & 0.6693 \\
\hline $1998-2001$ & $x$ & & & 0.0000 & 0.7508 \\
\hline 2002-2006 & $x$ & & & 0.0000 & 0.8070 \\
\hline $2007-2010$ & $x$ & & & 0.0000 & 0.8801 \\
\hline \multicolumn{6}{|c|}{0 -1 variables $x_{i}$} \\
\hline \multirow{4}{*}{ 1990-1997 } & $x_{1}$ & & & & 1 \\
\hline & $x_{2}$ & -0.2138 & 0.0226 & 0.0000 & 0.8075 \\
\hline & $x_{3}$ & -0.5847 & 0.0256 & 0.0000 & 0.5572 \\
\hline & $x_{4}$ & -1.4161 & 0.0348 & 0.0000 & 0.2427 \\
\hline \multirow{4}{*}{ 1998-2001 } & $x_{1}$ & & & & 1 \\
\hline & $x_{2}$ & -0.0949 & 0.0325 & 0.0035 & 0.9095 \\
\hline & $x_{3}$ & -0.1535 & 0.0337 & 0.0000 & 0.8577 \\
\hline & $x_{4}$ & -1.2400 & 0.0487 & 0.0000 & 0.2894 \\
\hline \multirow{4}{*}{$2002-2006$} & $x_{1}$ & & & & 1 \\
\hline & $x_{2}$ & 0.1476 & 0.0304 & 0.0000 & 1.1591 \\
\hline & $x_{3}$ & 0.0286 & 0.0323 & 0.3758 & 1.0290 \\
\hline & $x_{4}$ & -0.9814 & 0.0448 & 0.0000 & 0.3748 \\
\hline \multirow{4}{*}{ 2007-2010 } & $x_{1}$ & & & & 1 \\
\hline & $x_{2}$ & 0.0320 & 0.0314 & 0.3087 & 1.0325 \\
\hline & $x_{3}$ & 0.2993 & 0.0307 & 0.0000 & 1.3489 \\
\hline & $x_{4}$ & -0.8151 & 0.0430 & 0.0000 & 0.4426 \\
\hline
\end{tabular}

Source: own research.

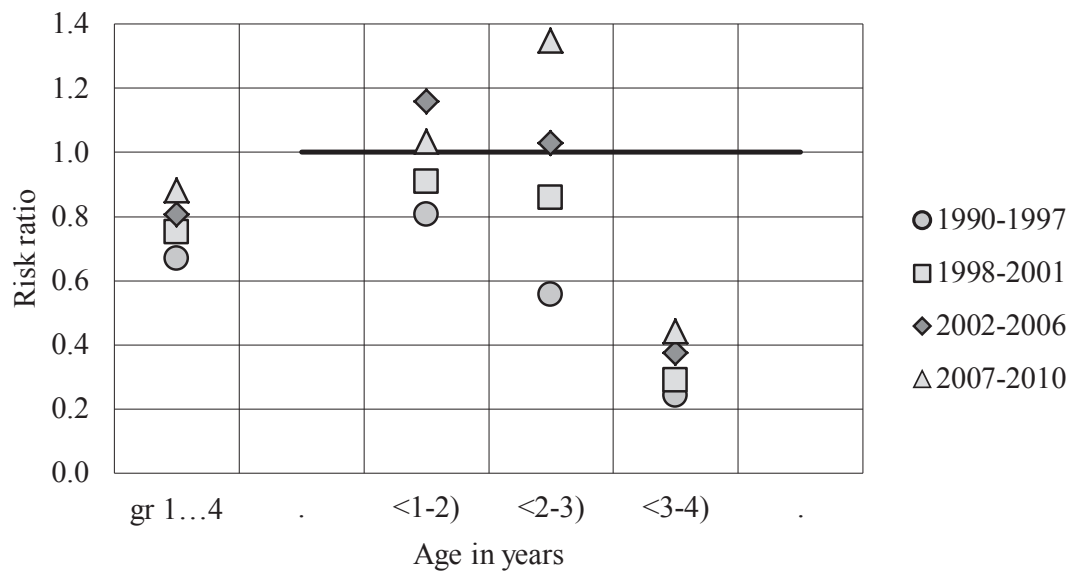

Fig. 5. Risk ratio of company liquidation for variables: rank and 0-1 (age in years) for the periods 1990-1997, 1998-2001, 2002-2006 and 2007-2010

Source: own research. 
of operation (to a greater extent in the first phase), while in the third and fourth phase (2002-2006 and 2007-2010) the risk initially grew and was smaller only in the oldest group.

\section{Conclusions}

Wiśniewski [1989] stresses that the possibilities of econometric modelling are greater when the 0-1 measurement is used rather than the rank measurement. The author refers this observation to qualitative endogenous variables. The results of the research presented in this article allow for a similar reference to quantitative explanatory variables. Better results in the sense of interpretation of the estimated parameters are obtained from the use of exogenous 0-1 variables than the rank or continuous variables.

The main conclusions of the research are as follows:

1. For companies established in Szczecin between 1990-2010:

- as the company aged by one month, the risk of its liquidation dropped on average by $43.22 \%$ (age as a continuous variable),

- as the company aged by one year, the risk of its liquidation dropped on average by $24.29 \%$ (rank variable),

- in comparison to companies aged one year, the risk of liquidation for two-year-old companies was lower by $6.27 \%$, for a three-year-old one - by $15.40 \%$, and for four-year-old ones - by as much as $68.87 \%$ (0-1 variable),

- in groups 1-8 (age expressed in half-years) the risk of liquidation in each subsequent group was lower by an average of $2.22 \%$ (rank variable),

- in comparison to the groups liquidated before reaching six months of age, the risk of liquidation was higher by $13.80 \%$ in group 2, higher by $5.29 \%$ in group 3 , lower by $4.59 \%$ in group 4 , higher by $1.23 \%$ in group 5 , lower by $19.59 \%$ in group 6 , lower by $49.41 \%$ in group 7 and lower by $82.66 \%$ in group $8(0-1$ variable).

2. For companies established in Szczecin in the cycles of 1990-2001 and 2002-2010 :

- as the company aged by one month, the risk of its liquidation dropped on average by $43.73 \%$ in the first cycle and by $42.27 \%$ in the second cycle (age as a continuous variable,

- as the company aged by one year, the risk of its liquidation dropped on average by $30.35 \%$ in the first cycle and by $15.65 \%$ in the second cycle (rank variable),

- in the first cycle the risk of liquidation in subsequent age groups was lower in comparison to the companies liquidated in their first year of operation, while in the second cycle it initially increased to fall only in the group of oldest companies (0-1 variable).

3. For companies established in Szczecin in 4 phases: 1990-1997, 1998-2001, 2002-2006, 2007-2010: 
- as the company aged by one month, the risk of its liquidation dropped on average by $42.93 \%$ in the first phase, by $45.30 \%$ in the second, by $42.36 \%$ in the third and by $42.16 \%$ in the fourth phase (age as a continuous variable),

- as the company aged by one year, the risk of its liquidation dropped in the four phases on average by $33.07 \%, 24.92 \%, 19.30 \%, 11.99 \%$ respectively (rank variable),

- in the two initial phases the risk of liquidation in subsequent groups was lower in comparison to the companies liquidated in their first year of operation, while in the third and fourth phases it initially rose to fall only in the group of oldest companies (0-1 variable).

\section{Bibliography}

Bednarski T., Mocarska E., 2006, On robust model selection within the Cox model, Econometrics Journal, vol. 9, pp. 279-290.

Bhattacharjee A., 2005, Models of Firm Dynamics and the Hazard Rate of Exits: Reconciling Theory and Evidence Using Hazard Regression Models, CRIEFF Discussion Papers 0502, Centre for Research into Industry, Enterprise, Finance and the Firm, University of St. Andrews.

Bieszk-Stolorz B., Markowicz I., 2017, Methods of event history analysis in the assessment of crisis impact on sectors related with the real estate market in Poland, Folia Oeconomica Stetinensia, vol. 17(1), pp. 57-67.

Carroll G.R., Hannan M.T., 2000, The Demography of Corporations and Industries, Princeton University Press.

Caves R.E., 1998, Industrial organization and new findings on the turnover and mobility of firms, Journal of Economic Literature, vol. 36(4), pp. 1947-1982.

Dehnel G., 2010, Rozwój mikroprzedsiębiorczości w Polsce w świetle estymacji dla małych domen, Wydawnictwo UE w Poznaniu, Poznań.

Ericson R., Pakes A., 1998, Empirical implications of alternative models of firm dynamics, Journal of Economic Theory, vol. 79(1), pp. 1-45.

Gatnar E., Walesiak M. (eds.), 2004, Metody statystycznej analizy wielowymiarowej w badaniach marketingowych, Wydawnictwo AE im. Oskara Langego, Wrocław.

Gruszczyński M. (ed.), 2012, Mikroekonometria. Modele i metody analizy danych indywidualnych, Oficyna, Wolters Kluwer S.A., Warszawa.

Gurgul H., Zając P., 2016, Modelowanie nieparametryczne czasu przeżycia przedsiębiorstw w Małopolsce, Wiadomości Statystyczne, nr 12, pp. 7-29.

Jackowska B., 2015, Analiza kohortowa czasu istnienia mikroprzedsiębiorstw w Gdańsku, Zarządzanie i Finanse, Journal of Management and Finance, vol. 13(4/2), pp. 127-145.

Jajuga K., 1990, Modele z dyskretna zmienna objaśniana, [in:] Estymacja modeli ekonometrycznych, Bartosiewicz S. (ed.), PWE, Warszawa.

Kleinbaum D.G., Klein M., 2005, Survival Analysis, Second Edit, Springer, New York.

López-Garcia P., Puente S., 2006, Business Demography in Spain: Determinants of Firm Survival, Documentos de Trabajo, no. 0608, Banco de España, Madrid.

Markowicz I., 2012, Statystyczna analiza żywotności firm, Rozprawy i Studia, t. (CMIX) 835, Wydawnictwo Naukowe Uniwersytetu Szczecińskiego, Szczecin.

Markowicz I., 2018, Modelowanie trwania firm powstatych $w$ Szczecinie w latach 1990-2013, Taksonomia 30, Klasyfikacja i analiza danych - teoria i zastosowania, Prace Naukowe Uniwersytetu Ekonomicznego we Wrocławiu, nr 507, pp. 142-150. 
Markowicz I., Mikulec A., 2018, Trwanie przedsiębiorstw w Łodzi i Szczecinie-analiza porównawcza, Taksonomia 30, Klasyfikacja i analiza danych - teoria i zastosowania, Prace Naukowe Uniwersytetu Ekonomicznego we Wrocławiu, nr 507, pp. 151-160.

Mikulec A., 2018, Kohortowe tablice trwania przedsiębiorstw w województwie tódzkim, Wiadomości Statystyczne, nr 5, pp. 56-77.

Nehrebecka N., Dzik A.M., 2013, Zdolność przetrwania przedsiębiorstw w Polsce, Wiadomości Statystyczne, $\mathrm{nr}$ 5, pp. 51-71.

Poznańska K., 2008, Cykle życia przedsiębiorstw a instytucjonalna infrastruktura ich funkcjonowania, [in:] Bankructwa przedsiębiorstw. Wybrane aspekty instytucjonalne, Mączyńska E. (ed.), Oficyna Wydawnicza SGH, Warszawa.

Praag C.M. van, 2003, Business survival and success of young small business owners: an empirical analysis, Small Business Economics, vol. 21(1), pp. 1-17.

Ptak-Chmielewska A., 2016, Determinanty przeżywalności mikro i małych przedsiębiorstw w Polsce, Oficyna Wydawnicza SGH, Warszawa.

Wiśniewski J.W., 1986, Ekonometryczne badanie zjawisk jakościowych. Studium metodologiczne, UMK, Toruń.

\section{ANALIZA RYZYKA LIKWIDACJI W ZALEŻNOŚCI OD WIEKU FIRMY NA PRZYKLADZIE PODMIOTÓW POWSTAŁYCH W SZCZECINIE W LATACH 1990-2010}

Streszczenie: Celem przeprowadzonych badań była ocena ryzyka względnego likwidacji firmy w zależności od jej wieku. Ich przedmiotem były podmioty gospodarcze powstałe w Szczecinie w latach 1990-2010. Analizę przeprowadzono z wykorzystaniem modelu logitowego. Ryzyko likwidacji firmy zbadano zarówno w zależności od wieku wyrażonego w miesiącach (zmienna ciągła), jak i w pogrupowanych przedziałach (rok, półrocze). Zwrócono w ten sposób uwagę na korzyści wynikające z kodowania zmiennych ciągłych (kodowanie rangowe i 0-1). Badania przeprowadzono dla firm powstałych w latach 1990-2010 ogółem (ponad 120 tys.) oraz w okresach wynikających z cykliczności likwidacji firm (wyniki poprzednich badań). Z badań wynika, że ryzyko likwidacji firmy wraz ze wzrostem wieku maleje (zastosowanie zmiennej ciągłej i zmiennej rangowej). Natomiast wartości ryzyka dla kolejnych grup wieku wskazują na to, że ryzyko nie przebiega monotonicznie.

Słowa kluczowe: analiza przeżycia, trwanie firm, ryzyko likwidacji. 